Web page: jurnal.ugm.ac.id/v3/jaci

\title{
Correlation between P-Wave Terminal Force V1 (PTFV1) from 12-Lead ECG and Left Ventricular Diastolic Dysfunction in Patients Diagnosed with Hypertension
}

\author{
Bambang Arie Hidayat Dalimunthe*, Nizam Akbar, Refli Hasan, Harris Hasan*, AndikaSitepu, Ali Nafiah Nasution
}

Department of Cardiology and Vascular Medicine, Faculty of Medicine, Universitas Sumatera Utara - H. Adam Malik General Hospital Medan, North Sumatera, Indonesia

\section{ARTICLE INFO}

*Corresponding author

email:

hasan1956@yahoo.com,

address:

Jl. Bunga Lau No. 17

Medan

Keywords:

diastolic dysfunction; PTFV1; electrocardiography

Manuscript submitted: October 27, 2019

Revised and accepted: January 18, 2020

\begin{abstract}
Background: Patients diagnosed with hypertension will deteriorate into hypertensive heart disease which is characterized by diastolic dysfunction first followed by systolic dysfunction later in the course of the disease. Diastolic dysfunction of the left ventricle causes an increase in LVEDP as well as in the dimension of the left atrium. P-Wave Terminal Force V1 (PTFV1) which is derived from 12 lead ECG could help diagnose diastolic dysfunction in centers where echocardiography is not available. The purpose of this study was to determine the correlation of PTFV1 on the 12-lead Electrocardiography with diastolic dysfunction in patients diagnosed with hypertension in the outpatient clinic of Cardiac Center Adam Malik General Hospital in Medan.
\end{abstract}

Methods: This is a cross-sectional study conducted from March 2019 until August 2019. Patients with hypertension who met the inclusion criteria were examined electrocardiographically to obtain PTFV1 value. Then echocardiography examination was then performed to assess the grades of diastolic dysfunction and other parameters. Analysis of correlation between PTFV1 values and diastolic dysfunction was then conducted.

Results: From the clinical characteristics, there is no difference regarding age, sex , and risk factorsbetween the three diastolic dysfunction groups, while echocardiography characteristic shows more reduced EF in grade III diastolic dysfunction (36.5 \pm 7.7$)$. Significant differences in PTFV1 are found among diastolic dysfunction groups. Grade I diastolic dysfunction has PTFV1 value of $23.8 \mathrm{~mm}$.ms, grade II diastolic dysfunction has PTFV1 value of $34.1 \mathrm{~mm} . \mathrm{ms}$, and grade III diastolic dysfunction has PTFV1 value of $52.1 \mathrm{~mm} . \mathrm{ms}$, Significance of $\mathrm{p}$ value is $<0.001$. There is a strong correlation between PTFV1 and diastolic dysfunction grade $(r=0.63(\mathrm{P}<0.001))$. Cut off point of PTFV1 > 29.8 mm.ms can discriminate patients who have increased LAP with a sensitivity of $84 \%$ and specificity of $71 \%$.

Conclusions: PTFV1 is a simple screening tool which is widely available and correlate well with left ventricular diastolic dysfunction in patients with hypertension, which makes it a good alternative tool especially in areas where echocardiography is not readily available.

\section{INTISARI}

Latar belakang: Penyakit hipertensi akan berlanjut menjadi penyakit jantung hipertensi yang ditandaidengan disfungsi diastolik yang kemudianberkembangmenjadidisfungsisistolik. Disfungsidiastolikdari ventrikel kiri akan menyebabkan peningkatan LVEDP dan dimensi dari atrium kiri. P-Wave Terminal Force V1 (PTFV1) dari EKG 12 lead dapat 
mempermudah deteksi disfungsi diastolik apabila tidak tersedia alat echocardiography. Tujuan penelitian ini adalah untuk mengetahui hubungan PTFV1 pada elektrokardiografi dengan disfungsi diastolik pada pasien dengan hipertensi di poliklinik rawat jalan Rumah Sakit Haji Adam Malik Medan.

Metode: Penelitian ini merupakan studi potong lintang yang dilakukan sejak Maret 2019 sampai Agustus 2019 pada pasien hipertensi di unit rawat jalan PJT RS HAM Medan. Pasien dengan hipertensi yang memenuhi kriteria inklusi akan dilakukan pemeriksaan elektrokardiografi untuk memperoleh nilai PTFV1. Kemudian dilakukan pemeriksaan echocardiography untuk menilai derajat disfungsi diastolik dan parameter lainnya. Kemudian dilakukan analisis hubungan antara nilai PTFV1 dan disfungsi diastolik.

Hasil : Dari karakteristik klinis, tidak dijumpai perbedaanumur, jenis kelamin, dan factor resiko diantara ketiga grup disfungsi diastolik, sementara dari hasil echocardiography dijumpai EF yang signifikan lebih rendah pada disfungsi diastolik grade III $(36,5 \pm 7,7)$. Dijumpai perbedaan signifikan dari PTFV1 diantara kelompok disfungsi diastolik. Disfungsi diastolik grade I dijumpai nilai PTFV1 23,8 mm.ms, disfungsi diastolik grade II dijumpai nilai 34,1 mm.ms, dan disfungsi diastolik grade III dijumpai nilai 52,1 mm.ms dengan nilai $\mathrm{p}$ value $<0,001$. Dijumpai korelasi kuat antara PTFV1 dengan grade disfungsi diastolik $(\mathrm{r}=0,63(\mathrm{P}<0,001)$ ). Titik potong Nilai PTFV1 sebesar 29,8 mm.ms dapat mendiskriminasi pasien dengan peningkatan LAP dengan sensitivitas $84 \%$ dan spesifisitas $71 \%$.

Kesimpulan: PTFV1 dapat menjadi alat bantu skrining yang sederhana, dan tersedia secara luas yang berkorelasi dengan grade disfungsi diastolic ventrikel kiri pada pasien dengan hipertensi, karena itu kegunaannya sangat potensial terutama di daerah yang tidak tersedia alat echocardiography.

\section{Introduction}

The increasing prevalence of hypertension every year is a major problem in both developed and developing countries. It is estimated that in 2025 the percentage of hypertensive patients will increase by $24 \%$ in developed countries. Whereas in developing countries the percentage of people with hypertension increases much higher at around $80 \%$. Indonesia is an example of a developing country with a high prevalence of hypertension. The average prevalence of hypertension throughout Indonesia is $29.8 \%$. Hypertension will progress into hypertension heart disease which is marked by left ventricular hypertrophy and diastolic dysfunction before eventually deteriorates into heart failure. ${ }^{1,2}$

One of the examination that is quite sensitive for the diagnosis of hypertension heart disease is echocardiography. However, this modality is not always available, especially in remote areas. P-terminal force V1 (PTFV1) measured from a 12-lead ECG is another alternative for assessing diastolic dysfunction, this parameter is the product of the duration and depth of the negative (terminal) part of the $P$ wave in the right precordial leads (especially lead V1). Morris and colleagues first introduced this concept, where a PTFV1 value equal to or more negative than $40 \mathrm{~mm} \cdot \mathrm{ms}$ could detect an enlarged left atrium in 211 patients with valvular heart disease. Because the structure of the left atrium will change significantly due to diastolic dysfunction, the PTFV1 measurement of a 12 lead ECG in patients with hypertension can provide information about said function. ${ }^{3,12}$ The purpose of this study is to assess the relationship between PTFV1 values from 12 lead ECGs and diastolic dysfunction parameters obtained from echocardiography in hypertensive patients in the cardiac center's outpatient clinic of H. Adam Malik (HAM) General Hospital, Medan.

\section{Methods}

This study is a cross-sectional diagnostic study conducted at the Department of Cardiology and Vascular Medicine, outpatient clinic of HAM General Hospital Cardiac Centre. Sample collection was carried out from March 2019 to August 2019. The inclusion criteria were subjects with lood pressure $\geq 140 / 90$ or patients with normal blood pressure but routinely taking hypertension medication. Exclusion criteria were patients with heart rhythm disorders, valve disorders due to rheumatic heart disease, moderate to severe functional disorders of the mitral or aortic valve, congenital heart diseases, pericardial abnormalities, patients who could not lie flat on the bed, and patients with poor echo window. Patients who met the inclusion criteria were then electrocardiographically and echocardiographically examined by one cardiology resident assisted by a cardiology nurse according to the study protocol.

\section{Study Protocol}

All samples in this study were patients with hypertension based on history taking and clinical symptoms that came to the cardiology outpatient clinic at HAM General 
Hospital. Researchers examined the patient's medical record to see the identity and basic data, history taking, and physical examination. Basic data were taken in the form of a history of previous illnesses, history of drug use, weight, height, and risk factors for cardiovascular disease. Patients who met the inclusion criteria were then given informed consent verbally and were recruited as research subjects if the patient was willing. Furthermore, for each research subject an electrocardiographic examination will be recorded using a Bionet Cardiotouch 3000 speed of 50 $\mathrm{mm} / \mathrm{s}$ and a scale of $20 \mathrm{~mm} / \mathrm{mV}$. The examination is carried out by a cardiology resident or nurse who is in charge of the cardiology outpatient clinic at HAM General Hospital and has been skilled in conducting electrocardiography examinations. P-terminal force at V1 (PTFV1) was measured by the multiplication between the duration and depth of the negative (terminal) part of the $\mathrm{P}$ wave in the right precordial leads (lead V1). Measurements were done manually using a $150 \mathrm{~mm}$ Krisbow vernier caliper micrometer (KW0600352) and a magnifying glass. The measurement results are reported in mm.ms units and will be validated by cardiologist on duty at cardiac center HAM General Hospital Medan.

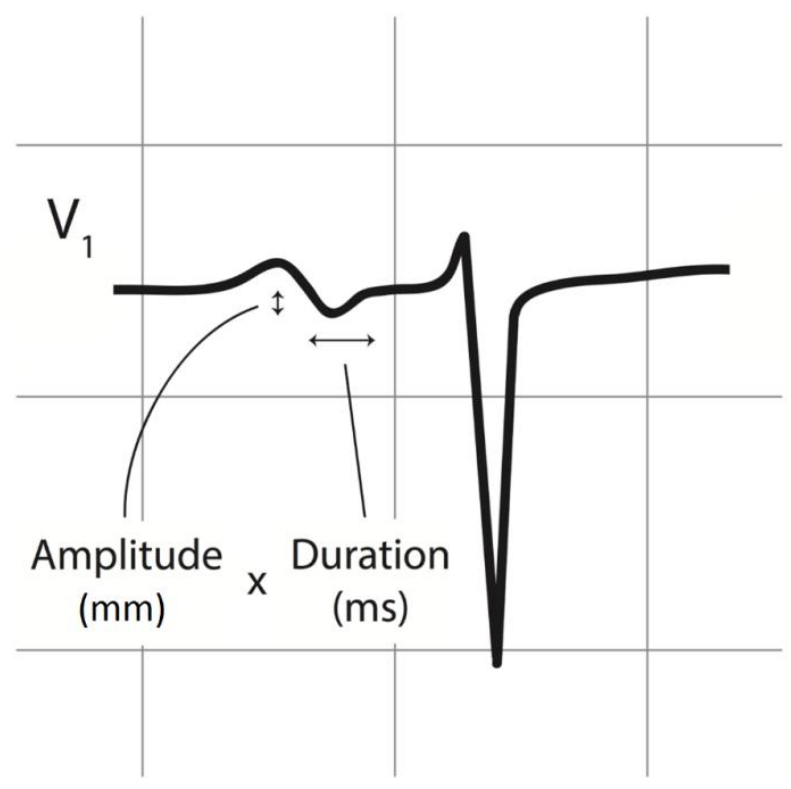

Figure 1. How to measure PTFV1. ${ }^{4}$

Patients who had been electrocardiographically examined were then performed echocardiography examination using GE Vivid S6 echocardiography with a $3.50 \mathrm{MHz}$ heart probe sector. Echocardiography was carried out by senior residents in the echocardiography room which was then validated by an echocardiographic supervisor. Ejection fraction (EF) was assessed by biplane (Simpson modification) or using auto EF. Left ventricular diastolic function is assessed according to the Doppler method of mitral inflow. The annulus velocity at the beginning of diastole (E), the annulus velocity at the end of diastole (A), and the E / A ratio, was assessed. This parameter was taken in the 4-chamber apical view by positioning the PW
Doppler sample volume (with a length of 1 to $2 \mathrm{~mm}$ ) in the middle of the leaflet tip of the opened mitral valve. Meanwhile, to obtain the septal e ', lateral e', and the ratio E / e ', Tissue Doppler Imaging (TDI) was used respectively in the septal and lateral side of the mitral annulus using the apical 4-chamber image. For LA volume ( $\mathrm{mL} / \mathrm{mm} 2$ ) biplane technique is used with apical 4chamber and apical 2-chamber display, at the end of systole. Echocardiography measurement results were then validated by cardiologist who was responsible in the Noninvasive / Echocardiography cardiac center of HAM General Hospital. The data analysis is performed with SPSS 23 to determine the relationship between PTFV1 values and left ventricular diastolic dysfunction.

\section{Statistical Analysis}

Data is presented by frequency and percentage for categorical data. While numerical data is presented by mean (average) and standard deviation for normally distributed data, whereas numerical data that is not normally distributed uses median (middle value). Baseline characteristics will be compared between groups with One Way Anova or Kruskal Wallis test and post hoc with Bonferroni or Games Howell for numeric variables and Chi-Square or Fisher's Exact Test for categorical variables. The correlation between PTFV1 values and left ventricular diastolic function was assessed by Pearson or Spearman correlation test. With ROC method, the area under the curve (AUC), the cut-off value, and the sensitivity and specificity values for the desired variables will be determined. Statistical analysis of the data was performed using SPSS software version 23, p values $<0.05$ were determined to be statistically significant.

Results

\section{Baseline Characteristics}

The total sample collected were 93 people who were then divided into three groups of diastolic dysfunction degree. The average age of the subject was 60 years, with a minimum age of 42 and a maximum of 80 years. No significant differences were found in the age of the subjects among the three diastolic dysfunction groups. In terms of sex, more male sex (75\%), compared with female sex $(23 \%)$ were found, no significant differences were found between diastolic dysfunction groups.There were no significant differences in risk factors between the three diastolic dysfunction groups. Research subjects had an average systolic blood pressure of 129 and a diastolic blood pressure of 77 , with an average pulse rate of 77 times per minute. The medication most consumed by subjects is ACE Inhibitor with 78 users or 83 percent of the subjects. When compared between diastolic dysfunction groups, no difference was found between blood pressure, pulse rate, or classes of antihypertensive drugs consumed. 
Table 1.

Baseline characteristics of the study subjects

\begin{tabular}{|c|c|c|c|c|}
\hline $\begin{array}{l}\text { Clinical } \\
\text { Parameters }\end{array}$ & $\begin{array}{l}\text { Diastolic } \\
\text { dysfunction } \\
\text { grade I } \\
(\mathrm{n}=31)\end{array}$ & $\begin{array}{l}\text { Diastolic } \\
\text { dysfunction } \\
\text { grade II } \\
(\mathrm{n}=31)\end{array}$ & $\begin{array}{l}\text { Diastolic } \\
\text { dysfunction } \\
\text { grade III } \\
(\mathrm{n}=31)\end{array}$ & P value \\
\hline $\begin{array}{l}\text { Age (years) } \\
\text { Genders : }\end{array}$ & $61.5 \pm 8.1$ & $59.7 \pm 8.9$ & $58.8 \pm 10.2$ & 0.491 \\
\hline Men (n (\%)) & 25 (80\%) & $24(77 \%)$ & $22(70 \%)$ & 0.659 \\
\hline Women (n (\%) & $6(19 \%)$ & $7(22 \%)$ & $9(29 \%)$ & \\
\hline $\begin{array}{l}\text { Smoking(n } \\
(\%))\end{array}$ & $18(58 \%)$ & $19(61 \%)$ & $19(61 \%)$ & 0.956 \\
\hline $\begin{array}{l}\text { DM } \\
\text { (n (\%)) }\end{array}$ & $10(32 \%)$ & $12(38 \%)$ & $9(29 \%)$ & 0.713 \\
\hline $\begin{array}{l}\text { Dislipidemia } \\
\text { (n (\%)) }\end{array}$ & $21(67 \%)$ & $22(70 \%)$ & $21(67 \%)$ & 0.951 \\
\hline $\begin{array}{l}\text { HT duration } \\
\text { (years) }\end{array}$ & $12(7-17)$ & $11(10-14$ & $13(7-17)$ & 0.737 \\
\hline $\begin{array}{l}\text { BW } \\
(\mathrm{kg})\end{array}$ & $71,8 \pm 14,2$ & $74.3 \pm 14.6$ & $66.8 \pm 11.2$ & 0.088 \\
\hline $\begin{array}{l}\text { Height } 9 \\
(\mathrm{~cm})\end{array}$ & $\begin{array}{l}164 \\
176)\end{array}$ & $\begin{array}{l}\text { 165(153- } \\
176)\end{array}$ & $\begin{array}{l}160 \\
(150-170)\end{array}$ & 0.239 \\
\hline $\begin{array}{l}\mathrm{BMI} \\
(\mathrm{kg} / \mathrm{m} 2)\end{array}$ & $\begin{array}{l}27.1 \\
(19-34)\end{array}$ & $\begin{array}{l}27.3 \\
(19-32)\end{array}$ & $\begin{array}{l}25.5 \\
(18.9-34.8)\end{array}$ & 0.161 \\
\hline SBP (mmHg) & $\begin{array}{l}130.0 \\
12.38\end{array}$ & $\begin{array}{l}128.7 \\
10.24\end{array}$ & $130.9 \pm 11.6$ & 0.733 \\
\hline $\begin{array}{l}\text { DBP } \\
\text { (mmHg) }\end{array}$ & $78.3 \pm 9.64$ & $75.8 \pm 10.2$ & $77.4 \pm 10.3$ & 0.598 \\
\hline $\begin{array}{l}\text { Heart Rate } \\
(\mathrm{bpm})\end{array}$ & $78.4 \pm 10.6$ & $75.7 \pm 11.1$ & $75.1 \pm 10.9$ & 0.447 \\
\hline $\begin{array}{l}\text { Beta blocker } \\
\text { (n (\%)) }\end{array}$ & $22(70 \%)$ & $20(64 \%)$ & $19(61 \%)$ & 0.716 \\
\hline $\begin{array}{l}\text { Ace Inhibitor } \\
\text { (n (\%)) }\end{array}$ & $25(80 \%)$ & 27 (87\%) & $26(83 \%)$ & 0.788 \\
\hline $\begin{array}{l}\text { CCB } \\
\text { (n (\%)) }\end{array}$ & $18(58 \%)$ & $20(64 \%)$ & $18(58 \%)$ & 0.836 \\
\hline $\begin{array}{l}\text { Diuretik } \\
\text { (n (\%)) }\end{array}$ & $18(58 \%)$ & $19(61 \%)$ & $16(51 \%)$ & 0.672 \\
\hline
\end{tabular}

From the ECG, significant differences were found in the PTFV1 value, which was $23.8 \mathrm{~mm} . \mathrm{ms}$ in grade I diastolic dysfunction, $34.1 \mathrm{~mm} . \mathrm{ms}$ in grade II diastolic dysfunction, and $52.1 \mathrm{~mm} . \mathrm{ms}$ in grade III diastolic dysfunction (P $<0.001$ ). From a post hoc analysis of significant groups, significant differences were found between all groups in PTFV1 parameters, either between grade I and grade II diastolic dysfunction groups, grade I and grade III diastolic dysfunction groups, or between grade II and grade III diastolic dysfunction groups. Another ECG parameter that has a significant difference between diastolic dysfunction groups is QTC. QRS duration. Presence of LVH strain and LVH voltage were not found significant among diastolic dysfunction grades.

From the echocardiography, there was a significant difference in the left ventricular ejection fraction which is lower $(36.5 \pm 7.7 \%)$ in the grade III diastolic dysfunction group compared to the other two diastolic dysfunction groups. Other LV Study parameters were also found different between diastolic dysfunction groups.

Correlation between P Wave Terminal Force V1 (PTFV1) and diastolic dysfunction

From the correlation analysis between PTFV1 and diastolic dysfunction grades, a strong correlation was found with $\mathrm{R}$ value of $0.63(\mathrm{P}<0.001)$. While from correlation analysis between PTFV1 values with each component of diastolic dysfunction, moderate correlation was found between PTFV1 values with E/A (R 0.48 P $<0.001)$ and $\mathrm{E} / \mathrm{E}^{\prime}(\mathrm{R}$ 0.54, $\mathrm{P}<0.001)$, and also a weak correlation between PTFV1 values and the anteroposterior LA dimension ( $\mathrm{R} 0.24, \mathrm{P}=0.02$ ).

Table 2.

ECG Characteristics of studysubject

\begin{tabular}{lllll}
\hline $\begin{array}{l}\text { ECG } \\
\text { Parameters }\end{array}$ & $\begin{array}{l}\text { Diastolic } \\
\text { dysfunction } \\
\text { gradeI } \\
\text { (n = 31) }\end{array}$ & $\begin{array}{l}\text { Diastolic } \\
\text { dysfunction } \\
\text { grade II } \\
(\mathrm{n}=31)\end{array}$ & $\begin{array}{l}\text { Diastolic } \\
\text { dysfunction } \\
\text { grade III } \\
\text { (n = 31) }\end{array}$ & P value \\
\hline $\begin{array}{l}\text { PTFV1 } \\
\text { (mm.ms) }\end{array}$ & $23.8(20.4-65.4)$ & $34.1(21.6-65.7)$ & $\begin{array}{l}52.1 \\
(22.3-67.8)\end{array}$ & $<0.001$ \\
$\begin{array}{l}\text { PR Interval } \\
\text { (ms) }\end{array}$ & $119(110-135)$ & $135(120-193)$ & $\begin{array}{l}148 \\
(114-192)\end{array}$ & $<0.001$ \\
$\begin{array}{l}\text { QRS duration } \\
\text { (ms) }\end{array}$ & $82.4 \pm 12.7$ & $84.1 \pm 8.7$ & $99.6 \pm 19.7$ & 0.300 \\
$\begin{array}{l}\text { QTc } \\
\text { (ms) }\end{array}$ & $386.9 \pm 38.0$ & $381.1 \pm 36.7$ & $474 \pm 37.1$ & $<0.001$ \\
$\begin{array}{l}\text { LVH Voltage } \\
(\mathrm{n}(\%))\end{array}$ & $18(58 \%)$ & $14(45 \%)$ & $12(38 \%)$ & 0.299 \\
$\begin{array}{l}\text { LVH Strain } \\
(\mathrm{n}(\%))\end{array}$ & $17(54 \%)$ & $17(54 \%)$ & $21(67 \%)$ & 0.396 \\
\hline
\end{tabular}

Table 3

Post hoc analysis of the ECG

\begin{tabular}{llll}
\hline ECG Parameters & DD grade I & DD grade I & DD grade II \\
& vs & vs & vs \\
& DDgrade II & DD grade III & DD grade III \\
\hline PTFV1 & P 0.001 & $\mathrm{P}<0.001$ & $\mathrm{P}<0.001$ \\
PR Interval & $\mathrm{P}<0,001$ & $\mathrm{P}<0.001$ & $\mathrm{P} 0.226$ \\
QTc & $\mathrm{P} 0.816$ & $\mathrm{P}<0.001$ & $\mathrm{P}<0.001$ \\
\hline
\end{tabular}

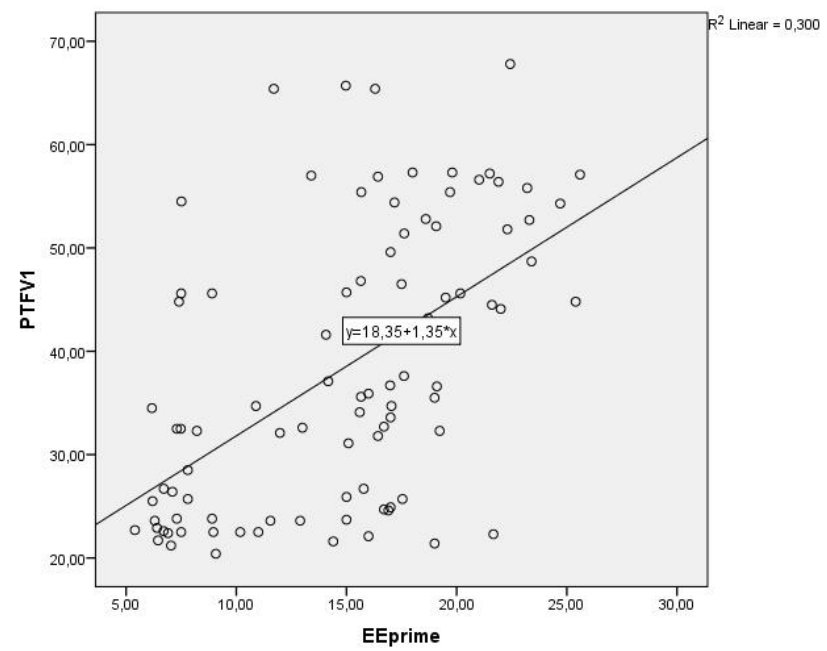

Figure 2. Scatter plot of PTFV1 and E/E' correlation 
Table 4

Echocardiography characteristics

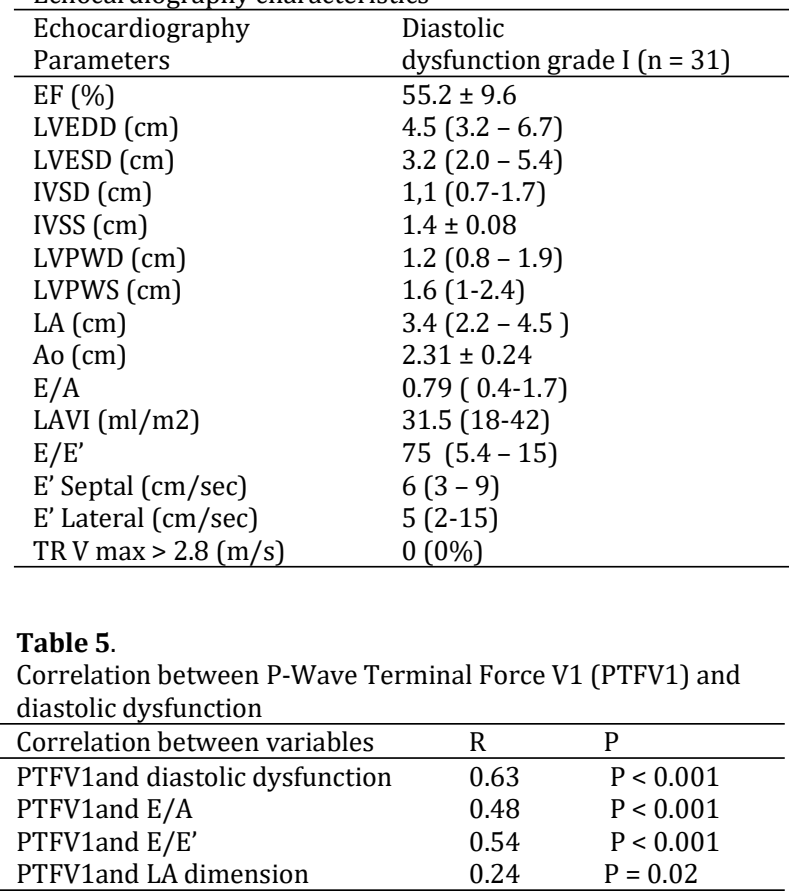

Cut off value of PTFV1 to determine diastolic dysfunction with increased LAP

From the obtained data, cut off value to differentiate diastolic dysfunction without an increase in LAP (grade I), with diastolic dysfunction with increased LAP (grade II and grade III) was calculated from the ROC curve analysis. The AUC was 0.815 with a P value $<0.001$. The best PTFV1 cut off point for to detect diastolic dysfunction with increased LAP is $29.8 \mathrm{~mm} . \mathrm{ms}$ which has a sensitivity of $83 \%$, specificity $71 \%$, positive predictive value $83 \%$, and negative predictive value $68 \%$.

\begin{tabular}{|c|c|c|c|c|}
\hline \multicolumn{5}{|c|}{$\begin{array}{l}\text { Table } 6 . \\
\text { Cut off point of PTFV1 to determine Diastolic dysfunction wit } \\
\text { increased LAP }\end{array}$} \\
\hline AUC & $P$ value & Cut off of PTFV1 & Sensitivity & Specificity \\
\hline 0.815 & $<0.001$ & $29.8 \mathrm{~mm} . \mathrm{ms}$ & $84 \%$ & $71 \%$ \\
\hline
\end{tabular}

\section{Discussion}

This is a cross-sectional diagnostic study that aims to examine the relationship between P-Wave Terminal Force V1 (PTFV1) from 12-lead electrocardiography with diastolic dysfunction in hypertensive patients. Based on the characteristics of the study subjects, the average age of was 60 years, this is in accordance with previous research by Tanoue et al. The aging process is thought to play a role as a substrate in the pathophysiology of diastolic dysfunction, although it is not yet fully understood. The aging process in diastolic dysfunction is evidenced by the presence of fibrosis on histopathological examination. ${ }^{5}$

\begin{tabular}{lll}
$\begin{array}{l}\text { Diastolic dysfunction } \\
\text { II }(\mathrm{n}=31)\end{array}$ & $\begin{array}{l}\text { Diastolic dysfunction } \\
\text { grade III }(\mathrm{n}=31)\end{array}$ & P value \\
\hline $50.3 \pm 11.9$ & $36.5 \pm 7.7$ & $<0.001$ \\
$5.0(3.5-6.7)$ & $5.7(3.2-6.8)$ & $<0.001$ \\
$3.7(2.3-5.7)$ & $4.7(2.3-6.0)$ & $<0.001$ \\
$1.1(0.8-1.5)$ & $0.9(0.6-1.2)$ & $<0.001$ \\
$1.2 \pm 0.09$ & $1.04 \pm 0.2$ & $<0.001$ \\
$1.2(0.8-1.7)$ & $1.0(0.4-1.3)$ & 0.001 \\
$1,5(1.0-2.2)$ & $1.3(0.6-1.6)$ & $<0.001$ \\
$3.2(2.6-4.8)$ & $4.0(2.4-4.6)$ & 0.84 \\
$2.32 \pm 0.42$ & $2.37 \pm 0.45$ & $<0.001$ \\
$1.2(0.56-1.9)$ & $2.5(2.0-2.59)$ & 0.027 \\
$33.6(25.3-51.3)$ & $34.1(26.4-38.2)$ & $<0.001$ \\
$15.6(10.8-17.6)$ & $19.8(13.4-25.6)$ & $<0,001$ \\
$4(1-8)$ & $4(2-6)$ & 0.001 \\
$8(5-17)$ & $7(5-13)$ & 0.009 \\
$6(19 \%)$ & $8(25 \%)$ &
\end{tabular}

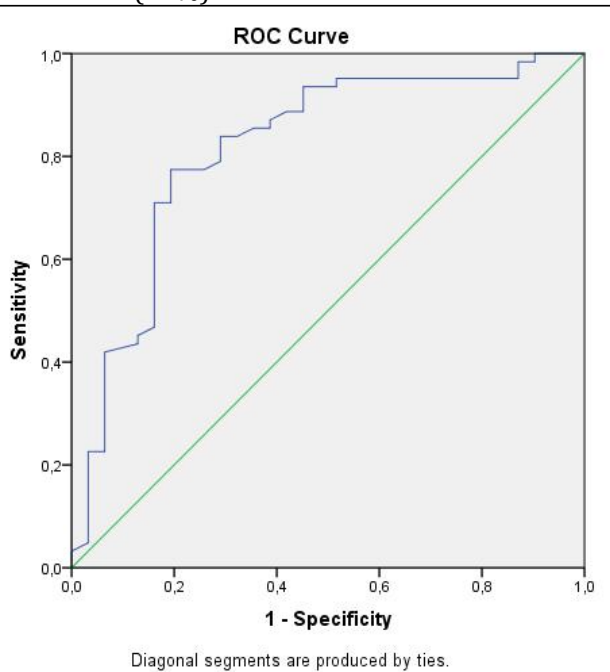

Figure 3. ROC curve of PTFV1 and diastolic dysfunction with increased LAP

From this study, the duration of hypertension in all groups was more than 10 years. However, there were no significant differences in the duration of hypertension between the diastolic dysfunction groups. Hypertension with a duration of $>5$ years has been shown to cause extensive left ventricular remodeling which will eventually increase the stiffness of the left ventricle, thereby affecting the diastolic function. ${ }^{6}$

From the echocardiography result, significant differences were found in the ejection fraction. In patients in the grade III diastolic dysfunction group, the mean EF was 36.5\%, while in the mild diastolic dysfunction grade, the average EF was $50-55 \%$. This is consistent with previous studies by Galderisi that restrictive filling patterns with a drastic increase in LVEDP in patients with HF are associated with a more severe category of heart failure, with a significant decrease in systolic function and even many have fallen into the category of end-stage heart failure. ${ }^{7}$

From the ECG parameters, significant differences were found in the PTFV1 value, where in grade I diastolic dysfunction group, the value was $23.8 \mathrm{~mm}$.ms, in grade II 
diastolic dysfunction it was $34.1 \mathrm{~mm} . \mathrm{ms}$, and in grade III diastolic dysfunction it was 52,1 mm.ms ( $\mathrm{P}<0.001$ ). In a previous study by Boles UA, et al who investigated PTFV1 in patients with and without diastolic dysfunction, echocardiography parameters for diastolic dysfunction were found to be statistically significant in patients with increased PTFV1 above $40 \mathrm{~mm} . \mathrm{ms}^{16}{ }^{16}$ Another study by Tanoue et al found a significant deterioration in E/A parameters in patients with PTFV1 $\geq 40 \mathrm{~mm}$.ms. (0.94 vs $0.85, \mathrm{P}=0.007) .^{5}$

The pathogenesis of hypertension is related to the occurrence of diastolic dysfunction with increased enddiastolic left ventricular pressure. These changes will eventually be transmitted to the left atrium which then undergoes continuous stretching and scarring. In another explanation, atrial changes mainly occur secondary to the pressure transmitted to the atrial wall from increased resistance in the initial diastolic filling phase. Furthermore, the left atrium which undergoes remodeling and geometrical changes will inhibit the propagation of electrical impulses, which then resulted in voltage conduction time augmentation time along with left posterior rotation of the $\mathrm{P}$ wave vector. This is what causes an increase in PTFV1. ${ }^{8,9,12}$

From this study, a strong correlation was found between PTFV1 and diastolic dysfunction, with an $R$ value of 0.63 ( $P<0.001)$. While from correlation analysis between PTFV1 with each component of diastolic dysfunction, a moderate correlation was found, and also a weak correlation between PTFV1 values and the anteroposterior LA dimension ( $\mathrm{R} 0.24, \mathrm{P}=0.02)$. PTFV1 itself is known to have a correlation with LA size and LA structure changes. The first study to explain this was the study by Morris, et al., Which found a significant correlation between increased PTFV1 and the size of the left atrium in patients with mitral valve lesions. The correlation strength obtained by Morris, et al is $\mathrm{R}=0.39$. PTFV1 in this study also has a moderate correlation with $\mathrm{E} / \mathrm{E}$ ' which is a marker of LAP, with a value of $\mathrm{R}=0.54$, and through ROC curve analysis, PTFV1 $\geq 29.8$ mm.ms can discriminate diastolic dysfunction with increased LAP (LAP) (grade II and grade III) from the one without increased LAP (grade I), the said cutoff value has a sensitivity of $83 \%$, and a specificity of $71 \%$, which is good., ${ }^{3,15}$ Previous research by Premindra A.N. et al regarding the relationship between PTFV1 values and LAP in post MI patients also showed a strong correlation between PTFV1 and an increase in LAP with $\mathrm{R}$ value of 0.78 . In that study patients with PTFV1 $\geq 30 \mathrm{~mm}$.ms were found to have increased LAP ( $>12 \mathrm{mmHg}$ ), and in patients with PTFV1 $<30$ mm.ms LAP tend to be normal. ${ }^{10}$ Another study by Jin L. et al also found that PTFV1 $\geq 40 \mathrm{~mm}$.ms had a sensitivity of $82 \%$ and a specificity of $40 \%$ to discriminate against patients with increased LAP. ${ }^{11}$

\section{Study Limitation}

This study is a single center experience so it is expected that further study can be done in multiple center in order to increase the reliability of research results. This study also has a data distribution that is not normally distributed so there are some extreme values that can affect the results of the study.

This study was a cross-sectional design, so no follow-up was done. Several studies of PTFV1 encountered relationships between PTFV1 and the incidence of cerebral infarction, atrial fibrillation, and sudden cardiac death. ${ }^{13,15}$ therefore, a prospective study investigating the relationship between PTFV1 and the prognosis of patients with hypertension should be strongly considered.

\section{Conclusion}

PTFV1 obtained from 12 lead ECG has a correlation with the grade of left ventricular diastolic dysfunction, E/A, E/E' value, and LA Dimension in patients with hypertensive heart disease. The cut-off point of PTFV1 $\geq$ $29.8 \mathrm{~mm} . \mathrm{ms}$ has a sensitivity of $84 \%$ and a specificity of $71 \%$ which is considered good in determining the presence of impaired diastolic function with increased LAP . PTFV1 values is a simple screening tool, which is widely available and correlate well with left ventricular diastolic dysfunction, hence the potential usage in areas where echocardiography is not readily available.

\section{References}

1. Kearny JB, Davis BR, Cutler J.1997. Prevention of heart failure by antihypertensive drug treatment in older persons with isolated systolic hypertension: SHEP Cooperative Research Group. JAMA, 278:212216.

2. Sundoro T. Riset Kesehatan Dasar (RISKESDAS) 2007. 2008. Laporan Nasional.Badan Penelitian dan Pengembangan Kesehatan, Departemen Kesehatan R.I. 134-135.

3. Morris JJ, Estes EH, Whalen RE, Thompson HR, McIntosh HD. 1964. P wave analysis in valvular heart disease. Circulation, 29:242-252.

4. Hooman K, Peter MO, Longstreth WT. 2015. Atrial cardiopathy: a broadened concept of left atrial thromboembolism beyond atrial fibrillation. Future Cardiol, 11: 323-331.

5. Tanoue TM, Sverre EK, Richard BD, Okin M. 2017. Relationship between abnormal P-wave terminal force in lead V1 and left ventricular diastolic dysfunction in hypertensive patients: the LIFE study. Blood Press, 26:94-101.

6. Kane GC, Karon BL, Mahoney DW. 2011. Progression of left ventricular diastolic dysfunction and risk of heart failure. JAMA, 306:856-863.

7. Galderisi M. 2005. Diastolic dysfunction and diastolic heart failure: diagnostic, prognostic and therapeutic aspects. Cardiovasc Ultrasound, 3:9.

8. Martin A, Alpert M, Kirubakaran M. 1989. Electrocardiographic diagnosis of left atrial enlargement. Arch Intern Med, 149:1161-1165.

9. Tereshchenko LG, Henrikson CA, Sotoodehnia N, Arking DE, Agarwal SK, Siscovick DS, et al. 2014. 
Electrocardiographic deep terminal negativity of the $P$ wave in $V(1)$ and risk of sudden cardiac death: the Atherosclerosis Risk in Communities (ARIC) study. J Am Heart Assoc, 3:e001387.

10. Chandraratna PA, Hodges M. 1973. Electrocardiographic evidence of left atrial hypertension in acute myocardial infarction. Circulation, 47:493-498.

11. Jin L, Weisse AB, Hernandez F, Jordan T. 1988. Significance of electrocardiographic isolated abnormal terminal P-wave force (left atrial abnormality). An echocardiographic and clinical correlation. Arch Intern Med, 148:1545-1549.

12. Mottram PM, Marwick TH. 2005. Assessment of diastolic function: what the general cardiologist needs to know. Heart, 91:681-695.

13. Kohsaka S, Sciacca RR, Sugioka K, Sacco RL, Homma S, Di Tullio MR. 2005. Electrocardiographic left atrial abnormalities and risk of ischemic stroke. Stroke, 36:2481-2483.

14. Tsao CW, Josephson ME, Hauser TH, O'Halloran TD, Agarwal A, Manning WJ, et al. 2008. Accuracy of electrocardiographic criteria for atrial enlargement: validation with cardiovascular magnetic resonance. J Cardiovasc Magn Reson, 10:7.

15. Soliman EZ, Prineas RJ, Case LD, Zhang ZM, Goff DC. 2009. Ethnic distribution of ECG predictors of atrial fibrillation and its impact on understanding the ethnic distribution of ischemic stroke in the Atherosclerosis Risk in Communities (ARIC) study. Stroke, 40:1204-1211.

16. Boles UA, Brown A. 2007. Relationship between P wave morphology and diastolic dysfunction in early hypertension. Irish J Med Scie, 176:391-392. 